\title{
KONSTRUKSI KONSEP SOCIAL DISTANCING DAN LOCKDOWN DALAM PERSPEKTIF KEBIJAKAN PUBLIK
}

\section{THE CONSTRUCTION OF SOCIAL DISTANCING AND LOCKDOWN CONCEPT IN THE PERSPECTIVE OF PUBLIC POLICY}

\author{
Dian Herdiana \\ Program Studi Administrasi Negara, Sekolah Tinggi Ilmu Administrasi (STIA) Cimahi \\ Email: kyberdian@gmail.com
}

Dikirim 6 Juni 2020, Direvisi 10 Juli 2020; Disetujui 27 Juli 2020

\begin{abstract}
Abstrak: Wabah COVID-19 yang melanda dunia memunculkan terminologi baru di tengah-tengah masyarakat, yaitu lockdown dan social distancing. Kedua terminologi ini merujuk kepada upaya yang dilakukan oleh pemerintah dalam penanggulangan COVID-19. Social distancing yaitu kebijakan pemerintah yang dibangun atas dasar upaya reduktif terhadap penyebaran penyakit di suatu wilayah yang berimplikasi kepada adanya pembatasan kegiatan dari penduduk dengan konsekuensi kewajiban pemerintah menetapkan instrumen kebijakan penentuan pola dan ruang kegiatan dari tiap penduduk. Lockdown yaitu kebijakan pemerintah yang dibangun atas kondisi penyebaran penyakit yang telah meluas di suatu wilayah yang berimplikasi kepada adanya pembatasan penduduk secara terpadu di wilayah tersebut dengan konsekuensi kewajiban pemerintah menetapkan instrumen kebijakan bagi keberlangsungan hidup penduduk. Berdasarkan kepada pemahaman tersebut, posisi pemerintah dalam konteks kebijakan social distancing berperan sebagai pengatur dan penentu atas aktivitas dari penduduk yang mana dalam batas-batas tertentu penduduk masih memiliki akses terhadap penghidupan seperti kepada sumber mata pencaharian, sedangkan posisi pemerintah dalam konteks kebijakan lockdown berperan sebagai pengendali dan penjamin keberlangsungan hidup penduduk dikarenakan hilangnya akses penduduk atas keberlangsungan hidup secara mandiri.
\end{abstract}

Kata kunci: COVID-19, Kebijakan Publik, Konsep, Lockdown, Social distancing.

\begin{abstract}
The outbreak of COVID-19 that hit the world gave rise to new terminology in the community, namely lockdown and social distancing. Both of these terms refer to the efforts made by the government in tackling COVID-19. Social distancing is a government policy that is built based on a reductive effort towards the spread of disease in an area which has implications for the limitation of activities of the population with the consequence of the government's obligation to set policy instruments for determining the spatial pattern of activity of each population. Lockdown is a government policy that is built on the condition of spreading of the disease that has spread widely in an area which has implications for systematic population restrictions in the region with the consequence of the government's obligation to set policy instruments for the survival of the population. Based on this understanding, the government's position in the context of social distancing policy acts as a regulator and determinant of the activities of the population which within certain limits the population still has access to livelihoods, while the government's position in the context of the lockdown policy acts as a controller and guarantor of the survival of the population due to the loss of population access to independent survival.
\end{abstract}

Keywords: COVID-19, Public Policy, Concepts, Lockdown, Social Distancing 


\section{PENDAHULUAN}

Kasus Corona Virus Disease 2019 (COVID-19) di Kota Wuhan China pada akhir tahun 2019 dengan cepat menyebar ke berbagai negara dan telah menginfeksi lebih dari 5 (lima) juta orang dengan lebih dari 300 (tiga ratus) ribu diantaranya meninggal dunia. COVID-19 menjadi penyakit pandemi di berbagai dunia yang mana pemerintah di berbagai negara menjadikan isu tersebut sebagai masalah publik yang harus segera ditanggulangi (World Health Organization, 2020; Worldometer, 2020).

COVID-19 yang awalnya merupakan masalah kesehatan tidak bisa lagi dipandang sebagai masalah kesehatan semata dikarenakan telah menimbulkan dampak negatif terhadap berbagai aspek kehidupan masyarakat mulai dari terganggunya ekonomi sampai dengan terganggunya aktivitas sosial kemasyarakatan. Kompleksitas dampak yang ditimbulkan akibat adanya pandemi COVID-19 menempatkan pemerintah sebagai institusi yang berada di garis terdepan dalam upaya penanggulangan COVID-19, pemerintah dituntut untuk menyusun instrumen kebijakan yang komprehensif tidak hanya dalam menanggulangi wabah penyakit COVID19, tetapi juga upaya perbaikan terhadap dampak yang ditimbulkan seperti dampak kepada kehidupan ekonomi, sosial dan kemasyakatan.

Upaya pemerintah di berbagai negara dalam menanggulangi COVID-19 memunculkan dua konsep yaitu social distancing dan lockdown yang mana kedua konsep tersebut memiliki dasar dan tujuan yang berbeda antara satu dengan yang lainnya. Konsep social distancing dan lockdown yang awalnya dipergunakan dalam dunia medis sebagai upaya untuk membendung penyebaran dan memberantas suatu penyakit kemudian berkembang dalam konteks yang jauh lebih luas dan diadopsi menjadi sebuah model kebijakan pemerintah yang secara substansi bersifat mengikat dan memiliki sanksi hukum apabila melanggarnya.

Pengembangan konsep social distancing dan lockdown yang menjadi instrumen kebijakan pemerintah berimplikasi kepada adanya tuntutan pengembangan konsep social distancing dan lockdown yang tidak hanya dilihat dalam perspektif kesehatan semata, tetapi juga dilihat dalam perspektif kebijakan publik yang mana baik dasar kebijakan maupun tujuan kebijakannya harus dapat dijelaskan menurut perspektif kebijakan publik.

Konsep social distancing dalam perspektif kebijakan publik dapat diartikan sebagai bentuk upaya pemerintah dalam penanggulangan penyebaran penyakit dengan tetap memberikan akses kepada penduduk di suatu wilayah untuk melaksanakan kegiatan tertentu khususnya dalam rangka memenuhi keberlangsungan hidupnya meskipun didasarkan kepada batasan-batasan yang telah dibuat.

Social diatancng merupakan upaya penanggulangan suatu penyakit dengan tetap memberikan hak-hak bagi penduduk di suatu wilayah yang terinfeksi penyakit (CDC, 2020; Pearce, 2020).

Konsep lockdown dalam perspektif kebijakan publik merupakan bentuk upaya pemerintah dalam penanggulangan penyebaran penyakit yang mana adanya larangan terhadap akses masuk dan keluar suatu wilayah, penduduk di suatu wilayah yang telah terinfeksi dilarang melakukan kegiatan termasuk didalamnya usaha pemenuhan keberlangsungan hidupnya, dengan begitu masyarakat diharuskan berada di rumah atau tempat yang telah disediakan oleh pemerintah agar tidak terinfeksi penyakit.

Berdasarkan kepada pemahaman tersebut maka social distancing menjadi suatu kebijakan pemerintah yang didasarkan kepada upaya untuk mereduksi penyebaran penyakit dengan tujuan selain dapat menanggulangi penyakit juga dapat tetap memberikan akses kepada masyarakat dalam penyelenggaraan hidupnya, sedangkan konsep lockdown merupakan 
bentuk kebijakan pemerintah yang secara menyeluruh menghilangkan akses penduduk untuk menyelenggarakan kehidupannya agar penanggulangan penyakit dapat dilakukan secara menyeluruh.

Pemahaman konseptual tersebut sejalan dengan pemahaman para pemangku kepentingan dan masyarakat yang selama pandemi COVID-19 terminologi social distancing dan lockdown sudah melekat dalam kehidupan sehari-hari yang mana banyak pihak dengan mudah menginterpretasikan kedua konsep tersebut sebagai batasan kegiatan (social distancing) dan penutupan/penguncian wilayah (lockdown).

Pemahaman tersebut perlu kiranya diperjelas dengan cara menguraikan secara lebih mendalam substansi apa yang ada apabila pemerintah mengambil kebijakan social distancing atau lockdown mengingat para pemangku kepentingan dan masyarakat tidak hanya dituntut untuk memahami secara umum kedua konsep tersebut, tetapi juga harus mengetahui dasar pengambilan kebijakan sampai dengan tujuan dari kedua konsep tersebut, sehingga pihak-pihak tersebut dapat berkontribusi aktif dalam pelaksanaan kebijakan penanggulangan COVID-19.

Urgensi akan tuntutan pemahaman yang lebih mendalam mengenai konsep social distancing dan lockdown sebagaimana dijelaskan di atas hingga saat ini kurang didukung oleh kajian konseptual terhadap social distancing dan lockdown itu sendiri, kajian konsep social distancing dan lockdown yang dikaitkan langsung dengan upaya penanggulangan COVID-19 masih minim dilakukan, terlebih lagi dilihat dalam perspektif kebijakan publik.

Didasarkan kepada hal tersebut diatas, maka artikel ini ditujukan guna membangun suatu pemahaman mengenai konsep social distancing dan lockdown yang dikaji dalam perspektif kebijakan publik yang mana alasan pengembangan konsep tersebut didasarkan kepada 3 (tiga) alasan utama, yaitu: Pertama, adanya kejelasan mengenai konsep social distancing dan lockdown mampu memberikan pemahaman kepada para pemangku kepentingan khususnya pemerintah mengenai ciri dan karakter dari kedua konsep tersebut, sehingga dalam proses penyusunan instrumen kebijakan penanggulangan COVID-19 akan mampu meminimalisir kesalahan interpretasi terhadap kedua konsep tersebut yang akan berimplikasi kepada kesalahan pemerintah dalam mengambil kebijakan penanggulangan COVID-19.

Kedua, kejelasan konsep social distancing dan lockdown yang diwujudkan melalui kejelasan instrumen kebijakan penanggulangan COVID-19 akan memberikan kepastian aturan bagi masyarakat sehingga masyarakat akan mampu mengikuti dan melaksanakan kebijakan tersebut sesuai dengan kapasitas dan perannya.

Ketiga, kejelasan konsep social distancing dan lockdown dapat dijadikan indikator pengukuran dalam menilai keberhasilan pemerintah dalam upayanya menanggulangi COVID-19 sehingga dapat menghasilkan pemahaman apakah upaya yang telah dilakukan baik itu melalui instrumen kebijakan social distancing atau instumen kebijakan lockdown telah tepat diambil dan dilaksanakan oleh pemerintah atau sebaliknya.

Berdasarkan uraian sebagaimana dijelaskan diatas, maka artikel ini diharapkan dapat memberikan kontribusi konseptual terhadap upaya penanggulangan COVID-19 khususnya dalam tataran konseptual berupa terbangunnya konsep social distancing dan lockdown yang dapat dipergunakan sebagai alternatif pemahaman bagi para pemangku kepentingan dan masyarakat dalam upayanya menyusun instrumen kebijakan penanggulangan COVID-19 maupun upaya penyusunan kebijakan rehabilitasi pasca pandemi COVID-19. 


\section{METODOLOGI}

Metode dalam penelitian ini menggunakan model-building method dengan pendekatan deskriptif, hal ini sejalan dengan tujuan penelitian yang ditujukan guna mengkonstruksikan konsep dari social distancing dan lockdown yang mana hasil akhir dari penelitian ini yaitu terbangunnya suatu model pengembangan konsep social distancing dan lockdown yang didasarkan kepada kajian empiris. Pemahaman tersebut telah sejalan dengan pendapat dari Shepherd \& Roy (2017) yang mengemukakan bahwa dasar empiris dapat dijadikan sebagai dasar dalam pengembangan suatu konsep. Pendekatan deskriptif dimaksudkan sebagai upaya menggambarkan temuan yang berupa penggambaran (deskripsi) kata-kata, bukan menyajikan hasil angka dari perhitungan statistik, ha ini sejalan dengan pemahaman Garna (1999) yang menyatakan bahwa dalam penelitian deskriptif data yang disajikan berupa penggambaran dalam bentuk kata-kata.

Data sekunder digunakan dalam penelitian ini yang mana sumber referensi yang relevan seperti buku, jurnal, peraturan perundang-undangan, laman web menjadi sumber dalam melakukan analisis. Data sekunder tersebut diolah kedalam tiga tahapan yaitu reduksi data, penyajian data/display dan penarikan kesimpulan Creswell (2007). Setelah proses pengolahan data dilakukan kemudian dilakukan pengujian guna menghasilkan data yang benar melalui proses triangulasi yang meliputi tahap check, tahap re-check dan tahap cross-check (Sugiyono, 2010).

\section{HASIL DAN PEMBAHASAN}

\section{A. Konstruksi Konsep Social distancing}

Social distancing menurut kamus Merriam Webster diartikan sebagai tindakan menjaga jarak fisik antara satu orang dengan orang lainnya dalam kondisi adanya penyebaran suatu penyakit
(Merriam Webster, 2020). Sementara menurut Center for Disease Control (CDC), social distancing diartikan sebagai tindakan menjauhi segala bentuk perkumpulan, jaga jarak antar manusia dan menghindari berbagai pertemuan yang melibatkan banyak orang (CDC, 2020). Sejalan dengan kedua pemahaman tersebut Pearce (2020) menyatakan bahwa: "Social distancing is a public health practice that aims to prevent sick people from coming in close contact with healthy people in order to reduce opportunities for disease transmission".

Berdasarkan kepada ketiga pemahaman tersebut di atas, maka dapat ditarik pemahaman bahwa social distancing merupakan tindakan pembatasan interaksi penduduk yang didasarkan kepada adanya penyebaran penyakit dengan tujuan mengurangi atau memperlambat penyebaran penyakit. Berdasarkan kepada pemahaman tersebut, maka tiga unsur utama dari social distancing yaitu: Pertama, adanya penyebaran suatu penyakit menjadi dasar tindakan dari social distancing. Kedua, pembatasan interaksi manusia yang secara praktis ditunjukan dengan menjaga jarak antar penduduk atau menghindari kerumunan. Ketiga, ditujukan untuk mengurangi atau memperlambat penyebaran penyakit (upaya reduktif).

Terminologi social distancing dalam perkembangannya oleh World Health Organization (WHO) diubah menjadi physical distancing dengan dasar bahwa batasan jarak yang dibuat didasarkan kepada diri pribadi individu secara fisik, bukan kepada kegiatan interaksi sosial yang mana hal tersebut tetap dapat dilakukan dalam bentuk komunikasi jarak jauh. Menyikapi pemahaman tersebut, baik social distancing maupun physical distancing memiliki substansi yang sama yaitu adanya pembatasan jarak fisik antar penduduk, sehingga dilihat dari perspektif konseptual keduanya memiliki kesamaan satu sama lainnya, sedangkan yang membedakan hanya pada makna bahasa antara social dengan physic yang kemudian dicoba digeneralisir kedalam konsep social 
distancing dan physical distancing yang kemudian melahirkan gagasan untuk membedakan diantara kedua konsep social distancing dan physical distancing.

Dikaitkan dengan konteks kajian kebijakan publik yang menempatkan pemerintah sebagai institusi negara yang memiliki kewenangan formal, maka social distancing merupakan salah satu respons pemerintah dalam bentuk penyusunan dan pelaksanaan kebijakan yang didasarkan kepada agenda isu berupa adanya penyebaran penyakit di suatu wilayah yang harus dilakukan upaya reduktif, sehingga melahirkan ketentuan yang harus dilaksanakan berupa penentuan pola dan ruang kegiatan dari tiap penduduk yang ada di wilayah tersebut. Berdasarkan kepada pemahaman ini, maka terminologi social distancing dalam konteks kajian kebijakan publik dapat diartikan sebagai kebijakan pemerintah yang dibangun atas dasar upaya reduktif terhadap penyebaran penyakit di suatu wilayah yang berimplikasi kepada adanya pembatasan kegiatan dari penduduk dengan konsekuensi kewajiban pemerintah menetapkan instrumen kebijakan penentuan pola dan ruang kegiatan dari tiap penduduk.

Berdasarkan kepada pengertian social distancing tersebut di atas, maka pemerintah dalam penyusunan dan pelaksanaan kebijakan social distancing dalam rangka reduksi terhadap penyebaran penyakit harus didasarkan kepada prasyarat yang harus dipenuhi yang dimulai dari landasan atau sebab dibuat dan diberlakukannya kebijakan social distancing sampai dengan tujuan yang hendak dicapai dari kebijakan social distancing tersebut. Alur pemahaman tersebut dapat dijelaskan melalui Gambar 1 berikut ini:

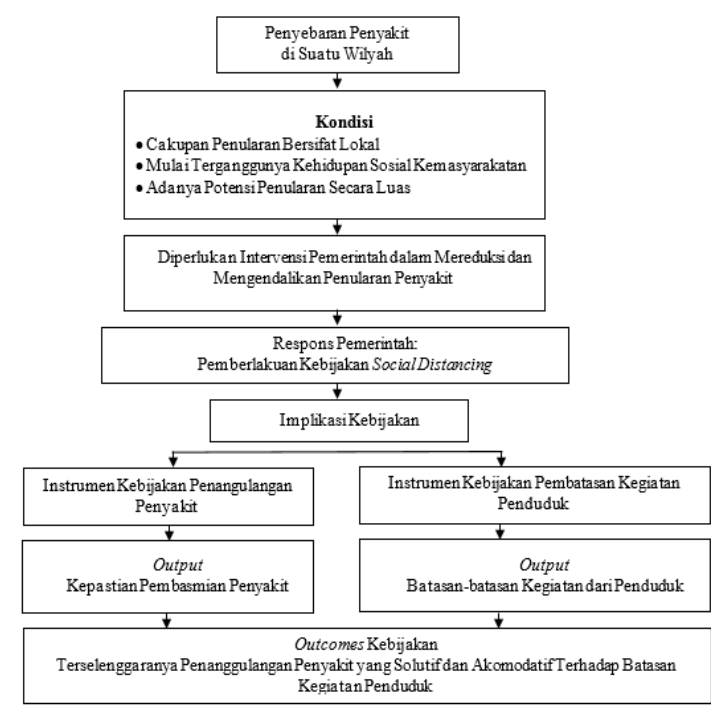

Gambar 1. Konstruksi Konsep Social Distancing

Sumber: Analisis Penulis, 2020

Berdasarkan kepada pemahaman dalam Gambar 1 tersebut di atas, maka dasar atau prakondisi yang menjadi dasar penetapan kebijakan social distancing setidaknya didasarkan kepada 3 (tiga) hal, yaitu: Pertama, adanya penemuan suatu penyakit yang telah menginfeksi penduduk, dalam artian penyakit tersebut telah diidentifikasi penyebarannya di suatu wilayah tertentu yang bersifat lokal. Kedua, penduduk merespons penyebaran tersebut dan menjadikan sebagai sebuah isu publik yang dalam batas-batas tertentu sudah meresahkan dan bahkan mengganggu terselenggaranya kehidupan sosial kemasyarakatan. Ketiga, hasil kajian membuktikan bahwa penyebaran penyakit tersebut berpotensi dapat menginfeksi penduduk secara luas.

Prakondisi tersebut harus disikapi oleh pemerintah melalui instrumen kebijakan penanggulangan penyakit dengan menggunakan pendekatan social distancing yang mana upaya yang dilakukan pemerintah di satu sisi diupayakan dapat mereduksi dan mengendalikan penyebaran penyakit, di sisi lainnya masyarakat masih memiliki akses terhadap keberlangsungan penghidupan penduduk meskipun dengan adanya batasan-batasan yang telah 

pemahaman tersebut, maka kebijakan penanggulangan penyebaran penyakit berdasarkan kepada konsep social distancing memiliki dua substansi kebijakan yaitu: Pertama, substansi mengenai penanggulangan penyakit. Kedua, substansi pembatasan bentuk kegiatan dari penduduk. Adapun uraian secara rinci dapat dijelaskan sebagai berikut:

Pertama, substansi mengenai penanggulangan penyakit. Dalam substansi kebijakan ini adanya rincian yang menjelaskan dimensi kebijakan yang secara langsung ditujukan untuk mereduksi dan mengendalikan penyebaran penyakit, seperti: a) dimensi pemetaan atau klasterisasi penyebaran penyakit yang didasarkan kepada penduduk yang telah terinfeksi, contohnya mengadakan uji kesehatan bagi tiap-tiap penduduk untuk mendapatkan data penduduk mana yang telah terinfeksi untuk kemudian dilakukan upaya karantina penduduk yang dimungkinkan sudah terpapar oleh penyakit dan harus dipisahkan dari penduduk yang lainnya, serta pemberlakuan isolasi penduduk yang terpapar dari penduduk lainnya yang sehat. b) Dimensi penanganan dan pengobatan bagi penduduk yang telah terinfeksi, contohnya yaitu menyediakan pusat kesehatan atau rumah sakit rujukan bagi penduduk untuk mendapatkan pengobatan. c). Dimensi lainnya seperti upaya penelitian dan pengujian terhadap awal mula, sebab adanya penyebaran penyakit, serta usaha penemuan obat dan upaya medis lainnya guna mereduksi dan mengendalikan penyebaran penyakit.

Kedua, substansi pembatasan bentuk kegiatan dari penduduk. Dalam substansi kebijakan ini adanya rincian yang menjelaskan mengenai dimensi yang secara langsung mengatur batasan-batasan dari kegiatan penduduk, seperti: a) dimensi batasan penduduk yang didalamnya memuat hal-hal apa saja yang boleh dan

kebijakan saja, semisa hanya memberlakukan pembatasan kegiatan tidak boleh dilakukan oleh penduduk seperti apakah penduduk masih bisa menjalankan mata pencaharian guna memenuhi kebutuhannya, mata pencaharian seperti apa yang dibolehkan dan dilarang. b). dimensi interaksi sosial yang didalamnya memuat hal-hal apa saja yang harus dipatuhi saat berada di muka umum seperti alasan apa yang diperbolehkan atau tidak diperbolehkan bagi penduduk untuk bisa berada di muka umum, pakaian atau alat perlindungan apa yang harus digunakan penduduk agar dapat berinteraksi di muka umum, bagaimana cara agar satu penduduk dapat berinteraksi dengan penduduk yang lainnya. c) Dimensi lainnya seperti adanya kebijakan bagi badan penyelenggaraan layanan publik yang memungkinkan penduduk untuk berinteraksi di muka umum, sehingga harus memiliki kejelasan prosedur. Uraian mengenai substansi kebijakan yang harus termuat dalam kebijakan social distancing beserta dengan dimensi yang harus ada di dalamnya bisa dijelaskan melalui Gambar 2 berikut ini:

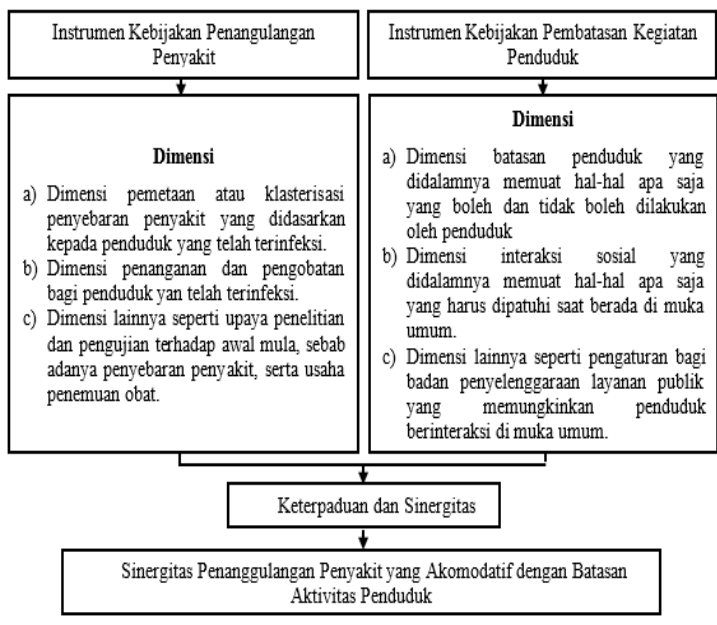

Gambar 2. Substansi Kebijakan Social Distancing

Sumber: Analisis Penulis, 2020.

Berdasarkan kepada gambar tersebut di atas, maka pemberlakuan kebijakan social distancing tidak bisa dilakukan hanya pada salah satu dimensi dalam instrument penduduk tanpa memberlakukan penanggulangan penyakit, begitupun 
sebaliknya. Dengan pemahaman tersebut maka keterpaduan/sinergi antar-dimensi dalam instrumen kebijakan yang satu dengan yang lainnya harus mampu melahirkan sinergitas pelaksanaan kebijakan social distancing yang diharapkan tidak hanya mampu mereduksi dan mengendalikan penyebaran penyakit, tetapi juga mampu menjaga keberlangsungan kehidupan penduduk meskipun adanya batasan-batasan.

\section{B. Konstruksi Konsep Lockdown}

Awal penyebaran COVID-19 yang terjadi di Kota Wuhan China pada akhir tahun 2019 menjadi perhatian dunia, pada saat itu WHO China Country Office menyatakan telah terjadi kasus pneumonia yang belum diketahui etiologinya, ratusan orang telah terinfeksi dan sebagiannya dinyatakan meninggal dunia (Putra, ZA, \& Bimo, 2020). Pemerintah China pada saat itu langsung mengambil kebijakan dengan melakukan penutupan/penguncian kota Wuhan guna menanggulangi kasus pneumonia tersebut, segala bentuk aktivitas kota dihentikan dan masyarakat diwajibkan untuk tinggal di rumah masing-masing. Implikasinya kota Wuhan seperti kota mati tanpa adanya penduduk yang melakukan aktivitas di ruang terbuka publik. Kebijakan pemerintah China yang menutup akses bagi kota Wuhan kemudian dikenal dengan istilah lockdown yang mana diinterpretasikan oleh masyarakat luas sebagai penguncian kota.

Kebijakan penutupan akses suatu wilayah sebagaimana dilakukan di kota Wuhan dilihat dari perspektif penanggulangan penyakit bukan merupakan hal yang baru, lockdown telah menjadi salah satu metode dalam dunia medis guna menanggulangi suatu wabah penyakit yang mana mobilitas penduduk di suatu wilayah diawasi secara ketat, pergerakan manusia di ruang terbuka publik menjadi terbatas atau dilarang sama sekali, praktek lockdown dalam sejarah secara empiris pernah dilakukan jauh sebelum adanya kasus COVID-19, seperti pada tahun 800 masehi yang mana wabah lanjutan Plague of Justinian melanda Eropa dan mengakibatkan kematian 200 juta jiwa, pada saat itu pemerintah Italia melarang para pelayar memasuki daratan dan ditahan di kapal mereka selama 30 hari dengan istilah quarantine yang kemudian menjadi asal kata dari "karantina"(Caspermeyer, 2016; Irlanda, 2020; Mordechai et al., 2019).

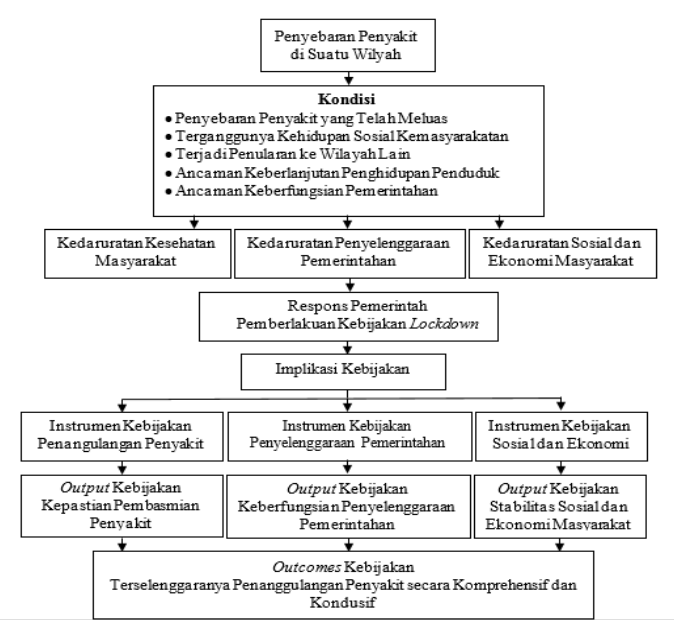

Gambar 3. Konstruksi Konsep Lockdown Sumber: Analisis Penulis, 2020.

Lockdown dalam penanggulangan penyakit secara empiris juga pernah diterapkan di Indonesia tepatnya pada masa penjajahan Hindia-Belanda yaitu pada saat terjadi wabah penyakit Pes pada tahun 1911 sampai dengan tahun 1912 yang mana pemerintah Hidia-Belanda melakukan karantina wilayah di Kota Malang guna menanggulangi penyebaran penyakit tersebut, bahkan pada saat itu pemerintahan Hindia-Belanda sengaja menyediakan pulau Onrust secara khusus yang letaknya tidak jauh dari Batavia untuk mengkarantina jamaah haji yang baru pulang dari Arab Saudi (Arsa, 2015; Widianto, 2020).

Berbagai kasus tersebut di atas menunjukan bahwa penyebaran penyakit yang berdampak luas terhadap keberlangsungan hidup manusia sudah terjadi sejak lama yang mana konsep lockdown juga telah diterapkan sejalan dengan upaya penanggulangan tersebut. 
Meskipun demikian konsep lockdown mengalami perkembangan sesuai dengan kebutuhan zaman.

Lockdown dalam konteks saat ini mengalami perkembangan yang disesuaikan dengan kebutuhan saat ini sebagaimana dapat dilihat dalam Gambar 3 yang mana lockdown merupakan bentuk penanggulangan penyakit yang didasarkan kepada prakondisi sudah meluasnya penyebaran penyakit dengan jumlah korban yang banyak serta sudah mengganggu dan meresahkan kehidupan masyarakat. Apabila penyakit tersebut tidak dilakukan upaya penanggulangan dengan cara menutup wilayah yang sudah terinfeksi oleh penyakit tersebut, maka dikhawatirkan akan menjadi ancaman bagi keberlanjutan kehidupan manusia, apabila hal ini terjadi maka sudah dapat dipastikan roda pemerintahan tidak bisa berjalan sebagaimana mestinya, dengan begitu konsep lockdown merupakan bentuk penanggulangan penyakit dengan cara menghentikan mobilitas penduduk baik yang akan masuk maupun yang akan keluar dari wilayah yangsudah terinfeksi penyakit.

Prakondisi tersebut sejalan dengan bukti empiris seperti upaya banyak negara dalam menanggulangi COVID-19 termasuk di dalamnya yang dilakukan oleh Pemerintah China mengunci kota Wuhan (Fang, Weedon, \& Handley, 2020), ketika penyebaran COVID-19 sudah meluas dan menimbulkan banyak korban, maka jalan terbaik untuk menanggulanginya yaitu dengan melakukan penguncian wilayah yang terinfeksi penyakit.

Kondisi penyebaran penyakit tersebut sudah pada tahap memberi dampak kepada tiga aspek utama, yaitu: Pertama, kondisi kesehatan masyarakat yang terganggu yang mana banyak masyarakat sudah terinfeksi dan diantaranya meninggal dunia, sehingga menimbulkan kekhawatiran akan dampak yang lebih besar yaitu lebih banyaknya masyarakat yang akan terinfeksi dan menjadi korban. Kondisi tersebut menimbulkan keadaan kedaruratan kesehatan masyarakat.

Kedua, penyebaran penyakit yang telah menginfeksi banyak penduduk secara langsung telah mengganggu jalannya roda pemerintahan, berbagai fungsi pemerintahan seperti pelayanan publik menjadi terganggu yang mana fungsi pemerintahan mengalami reorientasi dengan menitik beratkan kepada penanggulangan penyebaran penyakit, dengan begitu fungsi pemerintah lainnya seperti fungsi dalam bidang pendidikan, bidang kebudayaan, bidang pembangunan infrastruktur, bidang perekonomian dan bidang lainnya menjadi terganggu atau bahkan menjadi terhenti sama sekali. Kondisi tersebut melahirkan kedaruratan dari penyelenggaraan pemerintahan.

Ketiga, penyebaran penyakit yang telah meresahkan membuat kondisi di dalam masyarakat menjadi tidak stabil, masyarakat merasa ketakutan akan potensi terinfeksi sehingga kegiatan masyarakat dalam kondisi tidak normal mulai dari komunikasi sosial sampai dengan kegiatan perdagangan dan perekonomian. Kondisi tersebut mengakibatkan keadaan darurat bagi kehidupan sosial dan ekonomi masyarakat.

Implikasi dari keadaan darurat tersebut di atas memunculkan tuntutan agar penanggulangan penyebaran penyakit harus dilakukan secara komprehensif yaitu meliputi instrumen kebijakan penanggulangan penyakit, instrumen kebijakan penyelenggaraan pemerintahan dan instrumen kebijakan sosial ekonomi masyarakat. Dengan adanya ketiga instrumen tersebut diharapkan proses penanggulangan penyakit akan cepat dan berlangsung secara kondusif yang mana seluruh aspek penyelenggaraan kehidupan penduduk mulai dari aspek kesehatan sampai dengan aspek stabilitas ekonomi masyarakat dijamin oleh pemerintah, sehingga selain upaya tersebut dilakukan secara menyeluruh juga diikuti dengan cara 
untuk memberikan rasa kondusif bagi masyarakat.

Konsep lockdown sebagaimana dijelaskan tersebut di atas telah sejalan dengan kondisi di berbagai negara yang menerapkan lockdown bagi upaya penanggulangan COVID-19 yang mana kondisi kedaruratan baik kedaruratan kesehatan, kedaruratan penyelenggaraan pemerintahan dan kedaruratan sosial ekonomi masyarakat menjadikan masyarakat tidak memiliki akses terhadap penyelenggaraan kehidupannya secara mandiri, sehingga pemerintah hadir untuk menjadi katalisator keberlanjutan hidup penduduk. Pemerintah menjamin akses bagi masyarakat yang terinfeksi COVID-19 untuk mendapatkan penanggulangan COVID-19 di berbagai fasilitas kesehatan secara gratis, pemerintah juga turut hadir memastikan bahwa berbagai fungsi pemerintahan hadir untuk masyarakat serta keberlanjutan ekonomi masyarakat yang terganggu coba ditanggulangi oleh pemerintah dengan cara memberikan bantuan baik berupa pemenuhan bahan kebutuhan pokok maupun berupa tunjangan kesejahteraan sehingga adanya jaminan bagi keberlangsungan hidup penduduk.

Konsep lockdown apabila dilihat dalam perspektif hukum Indonesia yang mana didasarkan kepada Undang-Undang Nomor 6 Tahun 2018 tentang Kekarantinaan Wilayah (Pemerintah Indonesia, 2018) yang mana konsep lockdown diterjemahkan sebagai karantina wilayah, maka seluruh aspek keberlangsungan hidup penduduk dijamin oleh pemerintah sampai kepada pemenuhan kebutuhan dasar penduduk, hal ini termuat dalam Pasal 55 Ayat 1 yang berbunyi "Selama dalam Karantina Wilayah, kebutuhan hidup dasar orang dan makanan hewan ternak yang beradadi wilayah karantina menjadi tanggung jawabPemerintah Pusat". Adanya aturan tersebut menegaskan bahwa dalam menyusun kebijakan karantina wilayah, pemerintah mengadopsi prinsip lockdown yang menjamin keberlangsungan hidup dari penduduk yang berada di wilayah karantina.

Konstruksi konsep lockdown yang dibangun sebagaimana dijelaskan di atas telah sesuai dengan cara yang diterapkan pada saat ini dalam upaya penanggulangan COVID-19, sehingga konsep lockdown merupakan salah satu upaya dalam menanggulangi penyakit yang telah dipraktekan sejak dahulu hingga saat ini dengan dilakukan berbagai perkembangan sesuai tuntutan dan kebutuhan zaman.

\section{Pembatasan Sosial Berskala Besar (PSBB) Merupakan Perwujudan Konsep Social Distancing?}

Pembatasan Sosial Berskala Besar (PSBB) merupakan bentuk kebijakan dalam penanggulangan COVID-19 yang dituangkan dalam Peraturan Pemerintah Nomor 21 Tahun 2020 tentang Pembatasan Sosial Berskala Besar Dalam Rangka Percepatan Penanganan Corona Virus Disease 2019 (Pemerintah Indonesia, 2020), menjadi pertanyaan kemudian yaitu apakah kebijakan PSBB tersebut didasarkan kepada konsep social distancing ataukah memiliki konsep tersendiri yang berbeda dengan konsep social distancing?, menjawab pertanyaan tersebut maka terlebih dahulu harus diinterpretasikan pengertian PSBB sebagaimana tercantum dalam undang-undang yang ada.

PSBB diatur dalam Undang-Undang Nomor 6 Tahun 2018 Tentang Kekarantinaan Kesehatan yang mana dalam Pasal 1 Ayat 11 yang berbunyi: "Pembatasan Sosial Berskala Besar adalah pembatasan kegiatan tertentu penduduk dalam suatu wilayah yang diduga terinfeksi penyakit dan/atau terkontaminasi sedemikian rupa untuk mencegah kemungkinan penyebaran penyakit atau kontaminasi"'(Pemerintah Indonesia, 2018). Lebih lanjut PSBB dalam konteks penanggulangan COVID-19 diatur dalam Peraturan Pemerintah Nomor 21 Tahun 2020 Pasal 1 yang berbunyi: "Dalam Peraturan Pemerintah ini, yang dimaksud dengan Pembatasan Sosial Berskala Besar 
adalah pembatasan kegiatan tertentu penduduk dalam suatu wilayah yang diduga terinfeksi Corona Virus Disease 2019 (COVID-191 sedemikian rupa untuk mencegah kemungkinan penyebaran Corona Virus Disease 2019”. Lebih lanjut dalam Pasal 3 disebutkan mengenai kriteria PSBB yang berbunyi: "Pembatasan Sosial Berskala Besar harus memenuhi kriteria sebagai berikut: a. jumlah kasus dan atau jumlah kematian akibat penyakit meningkat dan menyebar secara signifikan dan cepat ke beberapa wilayah; dan $b$. terdapat kaitan epidemologis dengan kejadian serupa di wilayah atau negara lain".

Berdasarkan kepada pengertian tersebut maka dapat diuraikan prinsip-prinsip dari PSBB yaitu: Pertama, adanya penyebaran penyakit di suatu wilayah. Kedua, adanya pembatasan kegiatan tertentu yang diberlakukan bagi penduduk. Ketiga, penetapan kriteria yang dijadikan dasar berlakunya pembatasan sosial. Keempat, ditujukan untuk mencegah penyebaran penyakit. Berdasarkan kepada uraian prinsip-prinsip dalam kebijakan PSBB, maka dasar berlakunya PSBB dalam penanggulangan COVID-19 yaitu memberikan batasan-batasan kepada kegiatan dari penduduk, sehingga prinsipprinsip tersebut apabila dikorelasikan dengan konsep social distancing maka dapat dikatakan PSBB merupakan adopsi dari konsep social distancing.

Tabel 1. Korelasi PSBB dengan Konsep Social Distancing

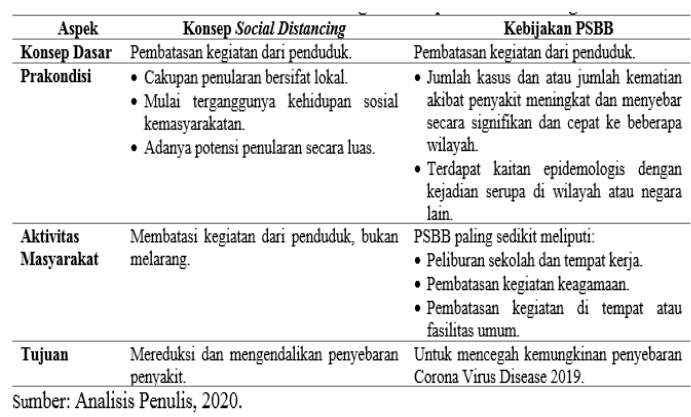

Berdasarkan kepada Tabel 1 di atas maka dapat dikonstruksikan pemahaman bahwa secara konseptual PSBB merupakan perwujudan dari konsep social distancing dalam konteks Indonesia. Meskipun demikian PSBB dalam tataran praktis tidak sepenuhnya menerapkan prinsip-prinsip PSBB, adapun beberapa perbedaannya dapat dijelaskan sebagai berikut:

Perbedaan pertama, prakondisi dalam menetapkan kebijakan PSBB tidaklah sama dengan prakondisi penetapan kebijakan social distancing. Dalam prakondisi kebijakan social distancing dicirikan dengan cakupan penularan yang masih bersifat lokal, sehingga upaya penerapan kebijakan social distancing ditujukan untuk melokalisir penyebaran penyakit, hal ini sejalan dengan tujuan kebijakan social distancing yaitu mereduksi dan mengendalikan penyebaran penyakit di suatu wilayah (upaya reduktif).

Kebijakan PSBB secara empiris diambil atas dasar kepada 2 (dua) kriteria utama yaitu: Pertama, jumlah kasus terinfeksi COVID-19 dan atau jumlah kematian akibat dari COVID-19 meningkat di kota atau kabupaten yang ada, sehingga menimbulkan kedaruratan dalam upaya penanganannya. Kedua, terdapat kaitan epidemologis dengan kejadian serupa baik di kota atau kabupaten lain dan di banyak negara, termasuk di hampir semua negara Kawasan ASEAN, atas dasar tersebut maka pemerintah menetapkan kebijakan PSBB bagi wilayah-wilayah (kaupaten/kota) dengan infeksi COVID-19 yang tinggi.

Kedua kriteria yang dijadikan dasar pemberlakuan PSBB tersebut di atas apabila dilihat secara keonseptual bukanlah prakondisi dari konsep social distancing, melainkan prakondisi dari konsep lockdown. Hal ini sejalan dengan uraian sebelumnya mengenai konstruksi konsep lockdown yang mana kebijakan lockdown akan diambil oleh pemerintah dengan prakondisi penyakit yang sudah menyebar secara luas dan menginfeksi lebih dari 1 (satu) wilayah.

Berdasarkan kepada pemahaman konseptual tersebut di atas, maka penyebaran COVID-19 yang menginfeksi dalam waktu yang cepat di banyak daerah 
harus direspons dengan memberlakukan kebijakan lockdown, bukan dengan memberlakukan kebijakan social distancing dikarenakan selain dasar prakondisi yang berbeda, juga dikarenakan proses dan tujuan dari pemberlakuan kebijakan tersebut akan berbeda pula yang mana kebijakan PSBB tidak ditujukan sebagai upaya reduktif tetapi ditujukan sebagai upaya penanggulangan COVID-19 yang harus melokalisir wilayah kabupaten/kota.

Penyebaran COVID-19 yang masih berlangsung hingga saat ini belum bisa membuktikan apakah prakondisi yang dijadikan dasar pemerintah untuk menetapkan kebijakan PSBB sudah tepat atau sebaliknya, mengingat kebijakan PSBB tengah berjalan dan belum dilakukan upaya evaluasi baik oleh pemerintah selaku pelaksana kebijakan PSBB maupun oleh pemangku kepentingan lainnya seperti institusi pendidikan, organisasi nonpemerintah (NGO) maupun organisasi lainnya. Hal yang dapat dimunculkan pada saat ini yaitu dengan menghasilkan dua pernyataan (conceptual statement), yaitu: Pertama, apabila kebijakan PSBB setelah dilakukan evaluasi nantinya dinyatakan berjalan efektif, maka pembentukan kriteria dalam penyusunan social distancing perlu dikaji ulang secara konseptual dikarenakan tidak relevan dengan kondisi empiris (kesalahan konsep) yang mana konsep social distancing tidak menunjang terhadap bukti empiris.

Kedua, apabila kebijakan PSBB setelah dilakukan evaluasi dan dinyatakan berjalan tidak efektif, maka penetapan kebijakan PSBB yang diambil oleh pemerintah didasarkan kepada kriteria yang salah yang mana kriteria yang diambil pemerintah tersebut seharusnya mengkonstruksikan penerapan kebijakan lockdown, bukan penerapan kebijakan social distancing (kesalahan pengambilan kebijakan).

Kedua pernyataan konseptual tersebut salah satunya akan memiliki kebenaran di masa yang akan datang setelah wabah COVID-19 berakhir dan dilakukan evaluasi. Adapun dasar dari pernyataan tersebut didasarkan kepada konsep public policy process yang mana berbagai ahli kebijakan seperti Tachjan (2008); Tangkilisan (2003) Jones (1984) menyatakan bahwa identifikasi isu publik dalam proses agenda setting akan menjadi dasar keberhasilan pelaksanaan kebijakan yang mana dapat dijelaskan dalam gambar 4 (empat) berikut ini:

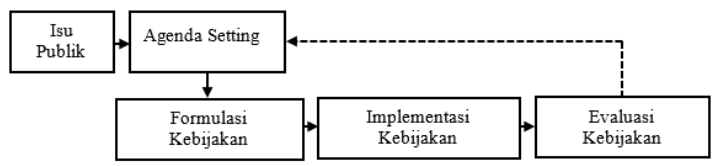

Gambar 4. Proses Kebijakan Publik Sumber: Analisis Penulis, 2020.

Berdasarkan kepada gambar 4 di atas, proses artikulasi isu publik yang dilakukan dalam tahapan agenda setting menjadi penting dan menentukan bagi kelancaran dan keberhasilan dalam menyusun kebijakan yang akan benar-benar menjadi solusi terhadap permasalahan yang ada di masyarakat, dalam konteks penanggulangan COVID-19 maka mengartikulasikan isu penyebaran COVID19 secara benar akan melahirkan kebijakan penanggulangan COVID-19 apakah melalui kebijakan social distancing atau melalui kebijakan lockdown yang apabila kebijakan tersebut berhasil atau gagal maka rujukan dasar keberhasilan atau kegagalan tersebut salah satu caranya yaitu dengan cara melihat proses artikulasi isu publik dalam tahapan agenda setting.

Perbedaan kedua, substansi pembatasan penduduk. Dalam kebijakan social distancing yang menjadi substansi pembatasan penduduk yaitu aktivitas dari penduduk yang mana diatur batasanbatasan dalam kegiatan penduduk. Sedangkan yang menjadi subsansi pembatasan dalam kebijakan lockdown yaitu pembatasan mobilitas penduduk yang mana akses penduduk dilarang untuk melakukan mobilisasi antar wilayah, pemerintah memberlakukan pengawasan dan penjagaan di setiap akses masuk dan keluar suatu wilayah yang telah ditetapkan 
sebagai lokasi pemberlakuan kebijakan social distancing (Nababan, 2020; Yasa, 2020).

Penerapan PSBB yang tengah dilaksanakan oleh pemerintah yang mana melarang penduduk untuk keluar atau masuk di wilayah yang tengah diterapkan PSBB dengan menugaskan aparat penegak hukum untuk menjaga setiap pintu perbatasan wilayah merupakan penerapan dari bentuk prinsip lockdown. Dengan adanya penerapan akses mobilitas penduduk maka pemerintah secara tidak langsung menerapkan kebijakan lockdown meskipun secara terminologi tidak menggunakan istilah lockdown atau karantina wilayah.

Implikasi dari adanya larangan mobilitas bagi penduduk tersebut secara empiris telah memberikan batasan yang tegas dan bahkan larangan bagi sebagian penduduk untuk menyelenggarakan usaha bagi keberlangsungan hidupnya, semisal seorang pedagang pakaian di sebuah pusat perbelanjaan harus berhenti berjualan dikarenakan pusat perbelanjaan tersebut ditutup oleh pemerintah, pedagang tersebut juga tidak diperkenankan untuk keluar dari wilayah yang tengah diberlakukan kebijakan PSBB, dengan begitu pedagang tersebut tidak bisa menjalankan keberlangsungan hidupnya secara mandiri. Apabila ditarik dalam perspektif kebijakan lockdown, maka adanya larangan yang dilakukan oleh pemerintah yang berimplikasi kepada berhentinya usaha keberlangsungan hidup seorang penduduk secara mandiri, maka pemerintah harus menanggung keberlangsungan hidup dari penduduk tersebut.

$\begin{array}{lrr}\text { Penerapan social distancing } \\ \text { mengkondisikan masyarakat } & \text { secara } \\ \text { berbeda dengan lockdown, semisal seorang } \\ \text { pedagang pakaian di sebuah pusat } \\ \text { perbelanjaan tidak bisa menyelenggarakan } \\ \text { usaha bagi keberlangsungan hidupnya } \\ \text { seperti biasa, dikarenakan hanya sedikit } \\ \text { orang yang berkunjung ke pusat } \\ \text { perbelanjaan sebagai akibat dari }\end{array}$

diberlakukannya pembatasan sosial yang menghimbau masyarakat untuk tetap berada di rumah. Dalam kondisi ini, meskipun pedagang tersebut mengalami kerugian, tetapi tidak ada larangan bagi penduduk untuk menyelenggarakan usaha bagi keberlangsungan hidupnya, sehingga tidak ada kewajiban bagi pemerintah untuk menanggung keberlangsungan hidup dari penduduk tersebut.

Berdasarkan kepada kajian pengaturan tentang PSBB, maka tidak diketemukan adanya aturan yang mengatur bagaimana pemerintah menjamin dan menjadi pengganti dalam menanggung keberlangsungan hidup dari penduduk yang kehilangan hak atas usaha keberlangsungan hidup penduduk secara mandiri, yang ada yaitu kebijakan jaminan keberlangsugan hidup yang dikategorikan sebagai keluarga miskin.

Kondisi tersebut menjadi salah satu kekurangan dalam substansi kebijakan PSBB yang mana harus adanya jaminan bagi keberlangsungan hidup penduduk yang secara sengaja terhenti karena adanya kebijakan pemerintah. Atas dasar tersebut maka menjadi keharusan bagi pemerintah untuk segera memasukan substansi kebijakan PSBB akan adanya jaminan bagi keberlangsungan hidup bagi para penduduk yang secara langsung tidak dapat menyelenggarakan usaha bagi keberlangsungan hidupnya.

Perbedaan ketiga, ukuran kinerja dan keberhasilan. Sebagaimana telah dijelaskan dalam pemaparan konstruksi konsep social distancing dan lockdown bahwa kedua konsep tersebut memiliki ukuran keberhasilan baik dalam proses pelaksanaan maupun dalam proses penilaian hasil/output. Dalam konsep social distancing ukuran yang digunakan yaitu ukuran penanggulangan penyakit dan ukuran pembatasan kegiatan penduduk, sedangkan dalam konsep lockdown ukuran yang digunakan yaitu ukuran batasan akses penduduk, ukuran penanggulangan penyakit, ukuran keberfungsian 
pemerintahan dan ukuran stabilitas sosial dan ekonomi kemasyarakatan. Dikaitkan dengan konteks kebijakan PSBB maka apa yang menjadi ukuran kinerja dan keberhasilan dari PSBB?

Berdasarkan kepada kajian terhadap aturan PSBB tidak dijelaskan seperti apa kinerja proses kebijakan, semisal dalam pemberlakuan PSBB selama 14 hari, apa yang harus dilakukan di hari pertama, di hari ke dua dan hari-hari berikutnya, siapa sasaran kebijakan di hari pertama, di hari kedua dan di hari-hari berikutnya. Aspek mana yang akan ditekankan di hari pertama, di hari kedua dan di hari-hari berikutnya dan ukuran apa yang akan digunakan untuk menilai keseluruhan proses dan implementasi dari kebijakan PSBB yang akan menghasilkan suatu penilaian apakah implementasi kebijakan PSBB terlaksana dengan baik dan berhasil atau sebaliknya.

Pengukuran kinerja dan keberhasilan kebijakan menjadi penting untuk disusun dan dibuat yang menjadi bagian dari substansi kebijakan PSBB itu sendiri, lebih lanjut ukuran kinerja dan keberhasilan tersebut harus diketahui oleh para pelaksana/implementor, para pemangku kepentingan dan masyarakat secara luas, mengingat adanya ukuran yang pasti akan kinerja dan keberhasilan kebijakan PSBB, selain akan memastikan pihak-pihak terkait untuk bekerja sesuai dengan perannya masing-masing juga diharapkan dapat menambah pengetahuan masyarakat yang mendorong untuk berpartisipasi dalam menyukseskan implementasi kebijakan PSBB tersebut.

Uraian dari ketiga perbedaan kebijakan PSBB dengan konsep social distancing sebagaimana dijelaskan di atas menunjukan bahwa dalam konteks Indonesia adopsi konsep penanggulangan COVID-19 tidak secara utuh didasarkan kepada satu konsep tertentu saja, tetapi dengan menggunakan penggabungan dari dua konsep yang ada, sehingga tidak hanya mengalami perbedaan dalam tataran implementasi secara empiris di lapangan, tetapi juga pada akhirnya akan memiliki perbedaan pula dalam menentukan tingkat keberhasilan dari kebijakan penanggulangan COVID-19 yang telah dilakukan, yang mana penggabungan kedua konsep tersebut akan menyulitkan terhadap penilaian kinerja implementasi kebijakan PSBB.

\section{SIMPULAN DAN SARAN}

Penanggulangan penyebaran penyakit di berbagai negara dilakukan secara berbeda, namun berbagai kebijakan tersebut pada dasarnya terpolarisasi kedalam dua konsep utama yaitu lockdown dan social distancing. Kebijakan social distancing diambil dalam konteks adanya upaya pencegahan dan pengendalian penyebaran penyakit agar tidak meluas dan berimplikasi kepada banyak aspek kehidupan masyarakat, hal ini sejalan dengan konsep social distancing yang merupakan tindakan yang dibangun atas dasar upaya reduktif terhadap penyebaran penyakit di suatu wilayah yang berimplikasi kepada adanya pembatasan kegiatan dari penduduk dengan konsekuensi kewajiban pemerintah menetapkan instrumen kebijakan penentuan pola dan ruang kegiatan dari tiap penduduk.

Kebijakan lockdown diambil dalam konteks upaya pengendalian menyeluruh atas penyebaran penyakit yang sudah menyebar secara luas dan telah mengganggu keberlangsungan kehidupan penduduk, hal ini sejalan dengan konsep lockdown itu sendiri yang merupakan tindakan yang dibangun atas prakondisi penyebaran penyakit yang telah meluas di suatu wilayah yang berimplikasi kepada adanya pembatasan penduduk di wilayah tersebut.

Prakondisi yang berbeda dari konsep lockdown dan social distancing berimplikasi kepada posisi pemerintah dalam pelaksanaan kedua kebijakan tersebut, dalam konteks kebijakan social distancing pemerintah berperan sebagai pengatur dan penentu atas aktivitas dari 
penduduk yang mana dalam batas-batas tertentu penduduk masih memiliki akses terhadap penghidupan seperti kepada sumber mata pencaharian. Sedangkan dalam konteks pelaksanaan kebijakan lockdown pemerintah berperan sebagai pengendali dan penjamin keberlangsungan hidup penduduk, hal ini didasarkan atas hilangnya akses masyarakat terhadap sumber mata pencaharian.

Saran yang diajukan dalam penelitian ini yaitu konsep social distancing dan lockdown dibangun atas dasar dan tujuan yang berbeda, konsistensi pemerintah menerapkan kebijakan penanggulangan COVID-19 yang didasarkan kepada salah satu konsep sangat dibutuhkan yang mana hal ini ditujukan selain untuk memberikan kepastian dan kemudahan bagi proses terselenggaranya penanggulangan COVID19, juga ditujukan untuk menjamin kemudahan penilaian keberhasilan atau kegagalan terhadap pelaksanaan kebijakan penanggulangan COVID-19 yang telah dilakukan oleh pemerintah, hal ini sebagai upaya menghindari adopsi prinsip dari konsep social distancing dan lockdown secara bersamaan yang pada akhirnya akan menyulitkan proses penilaian terhadap kebijakan yang telah dilaksanakan tersebut.

\section{DAFTAR PUSTAKA}

Arsa, D. (2015). Penyebaran Penyakit Wabah dan Tindakan Antisipatif Pemerintah Kolonial di Sumatra's Westkust (1873-1939). Turast: Jurnal Penelitian Dan Pengabdian, 3(2), 157-164.

Caspermeyer, J. (2016). Reconstructing the Sixth Century Plague from a Victim. Molecular Biology and Evolution, 33(11), 3028-3029. https://doi.org/10.1093/molbev/msw2 03

CDC. (2020). Social Distancing, Quarantine, and Isolation. Retrieved March 20, 2020, from https://www.cdc.gov/coronavirus/201 9-ncov/prevent-getting-sick/socialdistancing.html

Creswell, J. W. (2007). Qualitative Inquiry and Reseach Design: Choosing Among Five Approaches. Thousand Oaks: Sage Publications.

Fang, Ja., Weedon, A., \& Handley, E. (2020). Coronavirus COVID-19's Wuhan Lockdown: A Month On.

Garna, J. K. (1999). Filsafat dan Etika Pemerintahan. Bandung: Primaco Akademika.

Irlanda, S. F. (2020). 5 Pandemi Terburuk di Dunia sebelum Corona dalam Catatan Sejarah dan Bagaimana Akhirnya Berakhir. Retrieved from https://mataram.tribunnews.com/2020 /04/20/5-pandemi-terburuk-di-duniasebelum-corona-dalam-catatansejarah-dan-bagaimana-akhirnyaberakhir

Jones, C. O. (1984). An Introduction to the Study of Public Policy (Third Edit). California: Brooks/ Cole Publishing.

Merriam Webster. (2020). Social Distancing. Retrieved March 17, 2020, from https://www.merriamwebster.com/dictionary/social distancing

Mordechai, L., Eisenberg, M., Newfield, T. P., Izdebski, A., Kay, J. E., \& Poinar, H. (2019). The Justinianic Plague: An inconsequential pandemic? Proceedings of the National Academy of Sciences, 116(51), 25546 LP 25554.

https://doi.org/10.1073/pnas.1903797 116

Nababan, H. F. (2020). Mulai Jumat, Warga Wajib Tunjukkan Surat Izin KeluarMasuk Jakarta. Retrieved May 22, 2020, from https://bebas.kompas.id/baca/metro/2 020/05/20/mulai-jumat-warga-wajibtunjukkan-surat-izin-keluar-masukjakarta/

Pearce, K. (2020). What is Social 
Distancing and How Can It Slow The Spread of COVID-19. Retrieved March 20, 2020, from https://hub.jhu.edu/2020/03/13/whatis-social-distancing/

Pemerintah Indonesia. Undang-Undang Nomor 6 Tahun 2018 Tentang Kekarantinaan Kesehatan (2018). Indonesia.

Pemerintah Indonesia. Peraturan Pemerintah Nomor 21 Tahun 2020 Tentang Pembatasan Sosial Berskala Besar dalam Rangka Percepatan Penanganan Corona Virus Disease 2019 (COVID-19) (2020). Indonesia.

Putra, D. I., ZA, S., \& Bimo. (2020). Pedoman Umum Menghadapi Pandemi COVID-19 bagi Pemerintah Daerah: Pencegahan, Pengendalian, Diagnosis dan Manajemen. Jakarta: Kementerian Dalam Negeri RI.

Shepherd, D. A., \& Roy, S. (2017). Theory Building: A Review and Integration. Journal of Management, 43(1), 59-86. https://doi.org/10.1177/01492063166 47102

Sugiyono. (2010). Metode Penelitian Kuantitatif, Kualitatif \& Reseach and Development. Bandung: Alfabeta.

Tachjan. (2008). Implementasi Kebijakan Publik. Bandung: AIPI BandungPuslit KP2W Lemlit UNPAD.

Tangkilisan, H. N. S. (2003). Implementasi Kebijakan Publik. Jakarta: Lukman Offset.

Widianto, E. (2020). Lockdown, Belajar dari Sejarah Wabah Pes.

World Health Organization. (2020). Report of the WHO-China Joint Mission on Coronavirus Disease 2019 (COVID19). Geneva.

Worldometer. (2020). COVID-19 Coronavirus Pandemic. Retrieved April 11, 2020, from https://www.worldometers.info/coron avirus/
Yasa, A. (2020). Cek Fakta Jalan Tol Ditutup Antisipasi Corona, Ini Jawaban Jasa Marga. Retrieved May 22, 2020, from https://ekonomi.bisnis.com/read/2020 0323/45/1216688/cek-fakta-jalan-tolditutup-antisipasi-corona-inijawaban-jasa-marga 


\section{Halaman Kosong}

